\title{
Analisis work engagement karyawan frontline high-contact dan low-contact di industri jasa
}

\author{
Sucipto Asan* \\ Universitas Pelita Harapan \\ Jl. MH Thamrin Boulevard 1100, Karawaci, Tangerang, Banten 15811, Indonesia \\ sucipto.asan@uph.edu \\ Juanna Judith Huliselan \\ Universitas Pelita Harapan \\ Jl. MH Thamrin Boulevard 1100, Karawaci, Tangerang, Banten 15811, Indonesia \\ juanna.judith@uph.edu \\ *Penulis Korespondensi
}

Submitted: Mar 28, 2020; Reviewed: Apr 8, 2020; Accepted: Apr 18, 2020

\begin{abstract}
Work engagement (positive working mind and emotion) in frontline employees (FLEs) plays an important role that will affect the capability of the organization in serving its customer. The goal of this research is to examine whether there were differences in the influence of service climate, job satisfaction, and affective commitment toward work engagement in high-contact and low-contact frontline employees in Jakarta and Tangerang; and whether there were influences of work engagement toward adaptability behavior as well as career commitment among high-contact and lowcontact frontline employees. Questionnaire is administered to 200 FLEs from multiple high and low contact service industries in Jakarta and Tangerang. Structural Equation Modeling-Partial Least Square (SEM-PLS) is used to test hypotheses. The author found there were almost no differences among high-contact and low-contact frontline employees except on the job satisfaction, where there was no significant influence toward work engagement in frontline low-contact employee which was in contrast with the frontline high-contact employee. This research will enrich the discourse on the relationship between job satisfaction and work engagement. This finding provides empirical evidence on a limited scale that in certain segmentation, especially for low-contact workers, job satisfaction did not have a positive influence on work engagement.
\end{abstract}

Keywords: Adaptability; affective commitment; career commitment; job satisfaction; service climate; work engagement

Abstrak: Work engagement (pikiran dan emosi positif bekerja) di karyawan garis depan (frontline) memainkan peran penting yang akan mempengaruhi dan kemampuan organisasi dalam melayani pelanggannya. Penelitian ini untuk menguji apakah ada perbedaan pengaruh iklim layanan, kepuasan kerja, dan komitmen afektif terhadap work engagement pada karyawan frontline high-contact dan low-contact di Jakarta dan Tangerang; dan apakah ada pengaruh work engagement terhadap perilaku adaptabilitas serta komitmen karir di antara karyawan frontline high-contact dan lowcontact. Kuesioner yang diisi oleh 200 orang responden dikelola dalam penelitian ini. Semua responden merupakan karyawan FLE dari berbagai industri jasa yang bekerja di daerah Jakarta dan 
Tangerang. Pengujian hipotesis dalam penelitian ini menggunakan metode Structural Equation Modeling-Partial Least Square (SEM-PLS). Penulis menemukan hampir tidak ada perbedaan antara karyawan frontline high-contact dan low-contact, kecuali pada kepuasan kerja, yang mana tidak ada pengaruh yang signifikan terhadap keterlibatan kerja karyawan low-contact di garis depan yang berbeda dengan karyawan high-contact di garis depan. Penelitian ini akan memperkaya wacana tentang hubungan antara kepuasan kerja dan work engagement. Temuan ini memberikan bukti empiris pada skala terbatas bahwa dalam segmentasi tertentu, terutama untuk pekerja low-contact, kepuasan kerja tidak memiliki pengaruh positif pada work engagement.

Kata kunci: Adaptasi; iklim layanan; kepuasan kerja; komitmen afektif; komitmen karir; work engagement

\section{PENDAHULUAN}

Dalam lingkungan industri jasa, karyawan frontline (FL) adalah garda terdepan perusahaan. Mereka adalah touch point dalam sebuah customer experience journey. Informasi yang mereka sampaikan kerap kali lebih dipercaya dan dijadikan rujukan oleh para pelanggan (Karlsson \& Skålén, 2015). Posisi strategis karyawan FL memungkinkan mereka memiliki hak istimewa untuk melakukan tiga hal penting yakni: pertama, mengenal kebutuhan pelanggan dari "tangan-pertama" (Coelho, Augusto \& Lages, 2011); kedua, menjawab kebutuhan pelanggan yang unik dan beragam dalam waktu yang lumayan singkat (Wang \& Netemeyer, 2004); ketiga, pengetahuan dan pengalaman mereka dapat memberi masukan bagi pengembangan internal perusahaan bagi perbaikan (Plouffe, Bolander, Cote, \& Hochstein, 2015). Menurut laporan Mckinsey sejak 2010, perusahaan-perusahaan besar telah melakukan perubahan alokasi sumber daya dengan fokus yang lebih besar pada pengembangan kapabilitas kelompok karyawan $F L$. Hal ini dapat disimpulkan dari pertumbuhan fokus sumber daya pembelajaran dan pengembangan keterampilan lebih dari 1000 perusahaan. Tahun 2010, fokus sumber daya kepada karyawan FL adalah sebesar 22\%, melonjak naik menjadi 33\% pada tahun 2014 dan diperkirakan akan semakin naik di tahun-tahun mendatang (Benson-Armer, 2015).

Mengingat karyawan $F L$ memiliki peran yang penting dan strategis, maka keterlibatan pikiran dan emosi positif para karyawan $F L$ dengan pekerjaan mereka menjadi hal yang esensial. Keterlibatan pikiran dan emosi positif karyawan terhadap pekerjaan, dikenal dengan istilah work engagement. Banyak literatur yang ditulis mengenai keterhubungan work engagement, terutama menguraikan kaitannya dengan kinerja dan keunggulan bersaing organisasi (Kular, Gatenby, Rees, Soane, \& Truss, 2008) serta kepuasan dan loyalitas pelanggan (Harter, Schmidt, \& Hayes, 2002; Richman, 2006; Macey, Schneider, Barbara, \& Young, 2009).

Hal yang menarik adalah meskipun karyawan $F L$ dianggap penting, namun dalam kenyataannya tingkat engagement di kalangan karyawan $F L$ adalah termasuk salah satu yang paling rendah. Studi dari Bain \& Company tahun 2013 (Kaufman, Markey, Burton, \& Azzarello, 2013) terhadap 200.000 orang karyawan dari berbagai negara baik di Amerika maupun di Asia menegaskan hal ini. Mereka menggunakan Employee Net Promoting Score untuk mengukur tingkat engagement para karyawan tersebut dan menemukan bahwa kelompok kerja di divisi marketing, sales, customer service, IT, dan production adalah yang paling rendah. Tiga di antara kelompok kerja ini (marketing, sales, dan customer service) adalah para karyawan $F L$ yang langsung berhubungan dengan para pelanggan.

Mempertimbangkan fenomema di atas, ditambah belum banyaknya penelitian yang mengkaji faktor-faktor pendorong dan luaran dari work engagement dalam konteks layanan pelanggan, maka penulis tertarik untuk menganalisa faktor tersebut di kalangan karyawan FL high-contact dan lowcontact.

Schaufeli \& Bakker (2010) mendefinisikan work engagement sebagai "kondisi pikiran yang positif, membawa pemenuhan, yang terhubung dengan pekerjaan yang mencakup konsep semangat (vigor), dedikasi (dedication), dan keterhanyutan (absorption)". Maslach, Schaufeli, \& Leiter (2001) mengkonseptualisasikan work engagement sebagai lawan dari burnout (stres kerja yang membawa hal yang buruk dan tidak menyenangkan). Work engagement dapat dilihat sebagai keadaan pikiran dan emosi yang positif dan menyenangkan. Jika digambarkan dalam suatu kontinum, work engagement 
dan burnout berada dalam garis di kutub yang saling berlawanan. Work engagement di kutub positif sementara burnout di kutub negatif (Maslach et al., 2001; Schaufeli \& Bakker, 2004; Gorgievski, Bakker, \& Schaufeli, 2010). Kehadiran energi positif dalam work engagement merupakan kekuatan yang memotivasi karyawan untuk dapat meningkatkan kinerja pada level yang lebih tinggi. Sikap positif dan komitmen kuat tersebut membuat karyawan yang engaged berbeda dari yang lain (Wellins \& Concelman, 2005; Gorgievski et al., 2010).

Untuk memahami fenomena work engagement ini, teori Job Demand-Resource (JD-R) dan Conservatory of Resources akan membantu memberikan landasan terkait faktor yang membentuk dan mempengaruhi work engagement. Sementara teori Broaden and Build dapat memberikan landasan bagi luaran yang dihasilkan oleh work engagement.

Dalam teori JD-R, setiap pekerjaan memiliki karakteristiknya yang dapat dibagi dalam dua macam kategori, yakni job demand (tuntutan kerja) dan job resources (sumber daya kerja). Job demand adalah aspek fisik, psikologis, sosial, atau organisasional yang bersifat menuntut dari sebuah pekerjaan. Pekerjaan menuntut ketahanan fisik dan atau psikologis.

Job resources adalah aspek fisik, psikologis, sosial, atau organisasional yang menstimulasi pertumbuhan, pengembangan pribadi, dan pembelajaran (Bakker \& Demerouti, 2007). Interaksi antara job demand dan job resources merupakan elemen penting dalam pembentukan work engagement. Pekerjaan menghadirkan job demand baik secara fisik maupun emosi apabila diseimbangi dengan hadirnya job resources (seperti adanya umpan balik, otonomi, pengembangan diri, dukungan dari atasan, dan sebagainya), maka peningkatan work engagement dimungkinkan.

Teori Conservatory of Resources (COR) merupakan kerangka tambahan untuk membantu menjelaskan aspek apa saja yang dapat meningkatkan motivasi internal yang positif yang dikenal sebagai work engagement (Hobfoll, 1989). Menurut teori ini, dalam diri setiap manusia tersimpan suatu kesadaran bahwa sumber daya energi itu penting dan berharga. Oleh karena penting dan berharga, maka secara otomatis seorang pekerja akan berusaha menemukan, mempertahankan, serta melindungi sumber daya yang berharga tersebut.

Dalam kerangka teori COR, job resources dibagi dalam dua kategori yakni kategori eksternal dan internal (personal resources). Kategori eksternal dari job resources dapat berupa dukungan dari kolega, atasan, dan perusahaan. Job resources internal dapat berupa kondisi kognitif-afektif seseorang dalam bentuk keyakinan personal tertentu yang positif.

Dalam konteks karyawan $F L$, sumber daya penyangga dan penyeimbang (job resources) ekternal adalah dukungan kolega, atasan, dan atmosfir kerja. Barnes \& Collier (2013) menyebut fenomena ini sebagai hadirnya service climate.

Service climate dapat didefinisikan sebagai persepsi atas praktik, prosedur layanan terhadap pelanggan, dan perlakuan perusahan terhadap para karyawan $F L$ dalam bentuk dukungan, ekspektasi standar layanan, dan penghargaan (Schneider \& Bowen, 1993). Ada banyak penelitian yang mendukung hubungan antara atmosfir layanan dengan kualitas dan kepuasan pelanggan. Hubungan tersebut dimungkinkan karena adanya natur interpersonal dari service encounter, yang mana saat berinteraksi pelanggan dapat menilai langsung perilaku dari para $F L$ dan atmosfir layanan yang mengelilinginya (Johnson, 1996; Spector \& McCarthy, 2005; Mechinda \& Patterson, 2011).

Job resources internal dapat berupa kondisi kognitif-afektif seseorang dalam bentuk keyakinan personal tertentu yang positif. Keyakinan tersebut itu akan mendorong lahirnya perilaku-perilaku yang diperlukan untuk mencari sumber daya yang dibutuhkan untuk pencapaian sasaran, terutama saat orang tersebut sedang menghadapi tantangan dan juga persoalan (De Lange, de Witte, \& Notelaers, 2008; Schaufeli \& Bakker, 2004). Job demand resources internal yang diidentifikasi Barnes \& Collier (2013) adalah job satisfaction (keyakinan positif terhadap pekerjaan) dan affective commitment (keyakinan positif terhadap perusahaan).

Kepuasan kerja adalah sebuah kondisi emosi positif yang merupakan hasil dari penilaian individu tersebut atas pengalaman dan kebermaknaan dari pekerjaan yang ditekuninya (Locke, 1976; Johlke \& Duhan 2000; Kim, Lee, \& Murrmann, 2009; Parish, Berry, \& Lam, 2008; Homburg \& Stock, 2004).

Affective commitment (komitment afektif) dapat didefinisikan sebagai keterikatan emosional karyawan pada organisasi, identifikasi psikologis dengan identitas organisasi, dan keterlibatan emosional pada organisasi tersebut (Allen \& Meyer, 1990).

Kerangka teori emosi positif "Broaden-and-Build" (BB) membantu memberikan penjelasan bagi terbentuknya luaran work engagement (Fredrikson 1998; Fredrikson, 2004). Emosi positif (seperti rasa 
syukur, senang, bahagia, sukacita, rasa tertarik, dan keinginan untuk mengantisipasi sesuatu) dengan sendirinya akan "memperluas" (broadening) kesadaran dan keterampilan seseorang dan cenderung mendorong lahirnya pemikiran dan tindakan baru untuk melakukan eksplorasi atau building (Fredrickson, 2001).

Dalam konteks karyawan $F L$, work engagement yang dimiliki karayawan FL akan mendorong lahirnya perluasan kesadaran dan keterampilan yang berwujud dalam perilaku yang fleksibel, kreatif, dan terbuka. Perilaku tersebut oleh Barnes \& Collier (2013) disebut sebagai adaptability dan career commitment. Adaptability (adaptabilitas) merupakan perilaku adaptatif yang mewakili penyediaan alternatif layanan di luar layanan standar tertulis yang dilakukan atas dasar adanya kebutuhan solusi dari hasil olahan informasi yang muncul selama terjadinya service encounter (Gwinner, Bitner, Brown, \& Kumar, 2005).

Dalam prespektif 'build', seorang karyawan $F L$ yang memiliki work engagement akan cenderung mendorong lahirnya pemikiran dan tindakan baru untuk melakukan eksplorasi ke masa depan. Barnes \& Collier (2013) mengusulkan perilaku tersebut disebut sebagai career commitment.

Career commitment dipahami sebagai loyalitas seseorang terhadap profesi atau karir yang ditekuninya atau "perasaan positif terhadap tugas, peran, dan pekerjaan yang dijalani" (Mowday, Steers, \& Porter, 1979).

Kerangka berpikir yang digunakan dalam penelitian ini disadur dari penelitian Barnes \& Collier (2013). Pada Gambar 1 ditampilkan model penelitian tersebut yang berupa bentuk keterhubungan antar variabel yang diteliti, yakni service climate, job satisfaction, dan affective commitment terhadap work engagement serta work engagement terhadap adaptability dan career commitment.

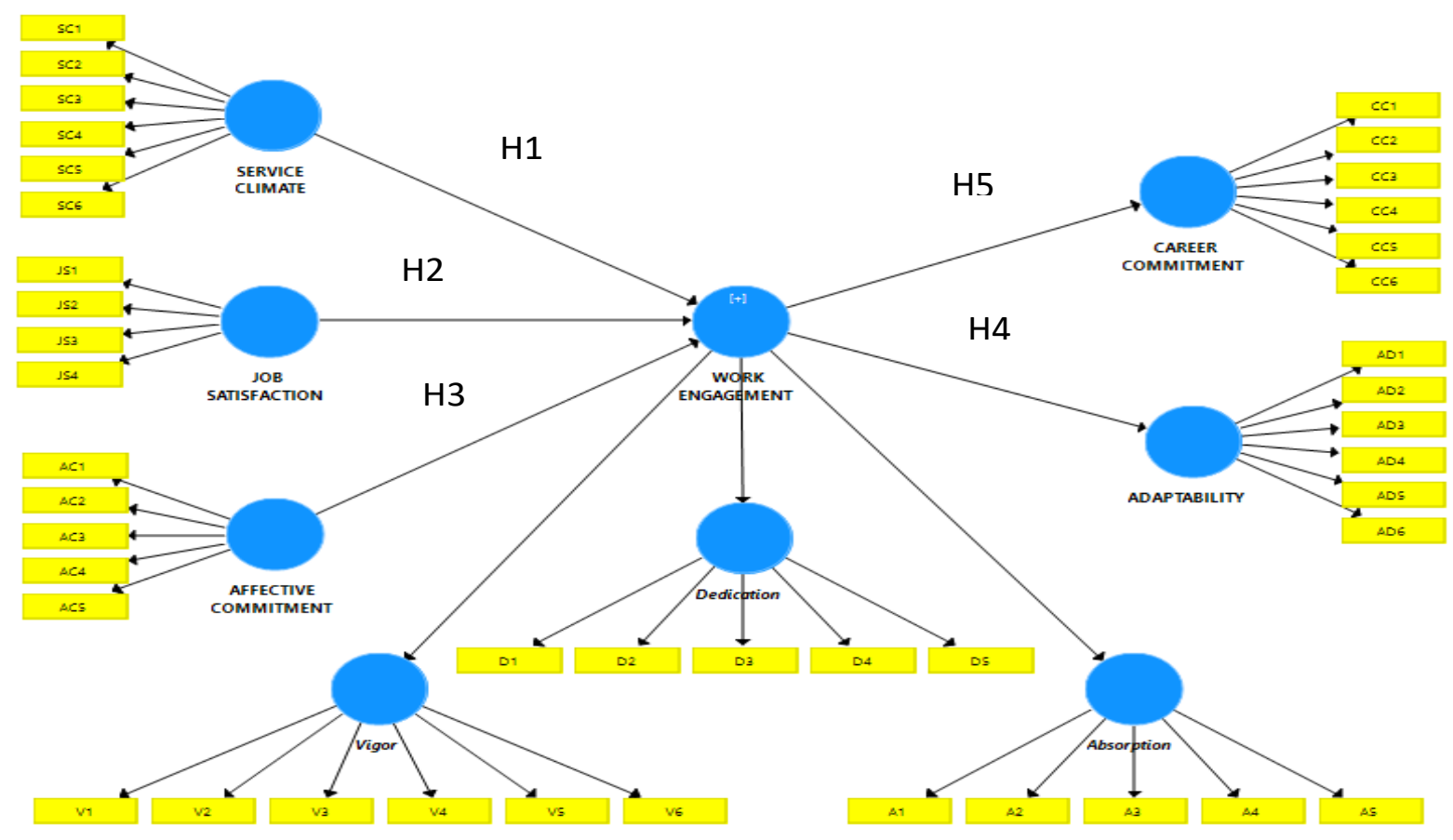

Gambar 1. Model penelitian

Sumber: Replikasi dari penelitian Barnes \& Collier (2013)

Oleh karena service climate berisi dukungan kolega, atasan, dan atmosfir kerja, maka hal ini dapat dikategorikan seabagai pilihan sumber daya (resources) penyeimbang dari job demand bagi seorang karyawan $F L$. Dengan menghadirkan service climate yang tepat maka dimungkinkan para karyawan FL terdorong untuk memunculkan kondisi pikiran yang positif (work engagement) terhadap pekerjaannya (Demerouti \& Cropanzano, 2010; Salanova \& Schaufeli, 2008), maka dapat dihipotesiskan sebagai berikut.

H1: Persepsi atas service climate memiliki pengaruh positif terhadap work engagement.

Dalam teori COR (Conservatory of Resources) dijelaskan bahwa setiap karyawan termotivasi untuk mencari dan menemukan sumber daya guna mengkompensasikan penurunan sumber daya 
(depletion of resources) akibat tuntutan pekerjaan (Hobfoll, 1989; Hobfoll, 1990). Job satisfaction atau kepuasan kerja merupakan salah satu dari emotional resource untuk mempertahankan semangat kerja (Amabile \& Kramer, 2011). Oleh karena job satisfaction (kepuasan kerja) merupakan aspek afeksi dalam bentuk mood seseorang terhadap pekerjaannya (Schaufeli \& Bakker, 2010) serta wujud dari rasa aman dan relaksasi atas pekerjaan yang ditekuni (Macey \& Schneider, 2008; Schaufeli \& Bakker, 2010), maka dapat dihipotesiskan sebagai berikut.

$\mathrm{H} 2$ : Job satisfaction memiliki pengaruh positif terhadap work engagement

Teori identitas sosial menegaskan bahwa komitmen terhadap organisasi akan mendahului sikap terhadap kerja (Tajfel \& Turner, 1985). Dengan kata lain, sebagai pekerja atau karyawan yang memiliki kebanggaan dan rasa afektif kepada organisasi akan mendorong keinginan yang besar untuk memastikan keberhasilan organisasi melalui apa yang ia tekuni dan dengan demikian akan melahirkan emosi positif atau antusiasme atas pekerjaan tersebut, maka dapat dihipotesiskan sebagai berikut.

H3: Affective commitment memiliki pengaruh positif terhadap work engagement

Ada beberapa penelitian yang memberikan indikasi bahwa emosi positif dan antusiasme seseorang atas pekerjaan yang ditekuni akan menyebabkan lahirnya sikap empati yang berbentuk perilaku adaptatif yang bertujuan membantu pelanggan untuk memenuhi kebutuhannya dengan sebaik-baiknya (Lybomirsky, King, \& Diener, 2005; Isen, 1984; Hakanen, Perhomeini, \& Toppinen-Tanner, 2008), maka dapat dihipotesiskan sebagai berikut.

H4: Work engagement memiliki pengaruh positif terhadap adaptability

Ada beberapa penelitian yang mengindikasikan bahwa emosi positif dan antusiasme atas pekerjaan seseorang terhubung dengan perilaku career commitment, seperti rendahnya pengunduran diri dan rendahnya angka keluar-masuk karyawan, menurunnya jumlah karyawan yang mangkir kerja, serta meningkatnya perilaku yang selaras dengan nilai organisasi (George, 1989; Pelled \& Xin, 1999), maka dapat dihipotesiskan sebagai berikut.

H5: Work engagement memiliki pengaruh positif terhadap career commitment

\section{METODE}

Penelitian dilakukan terhadap karyawan $F L$, baik laki-laki ataupun perempuan yang sudah bekerja minimal 1 (satu) tahun pada perusahaan jasa kategori high-contact seperti (1) pendidikan, (2) perbankan, dan (3) restoran, serta kategori jasa low-contact seperti (1) TV kabel, (2) internet service provider, dan (3) toko retail yang berlokasi di sekitar Jakarta dan Tangerang.

Peneliti menggunakan data primer yang diperoleh dengan menyebarkan kuesioner kepada 300 orang responden yang berada di daerah Jakarta dan Tangerang. Responden yang mengembalikan kuesioner sebanyak 208 orang. Namun 8 orang responden di antaranya tidak valid, sehingga hanya total 200 orang responden yang datanya dapat diolah. Untuk keperluan analisis, kuesioner diberikan bobot penilaian untuk setiap pernyataan dalam skala Likert 1-5 dengan keterangan jawaban tidak pernah diberi skor 1 sampai dengan selalu diberikan skor 5. Pengolahan data aktual dilakukan dengan menggunakan metode Strutural Equation Modeling-Partial Least Square (SEM-PLS) yang dikelola dengan menggunakan aplikasi progam Smart PLS 3.0.

Analisis Outer Model Measurement (Uji Validitas dan Realibilitas)

Uji validasi penelitian terdiri dari uji model pengukuran (outer model), uji model struktural (inner model), dan uji hipotesis. Validasi dilakukan dengan menilai hasil outer loading dan average varian extracted (AVE), dengan tujuan untuk mengetahui apakah pernyataan-pernyataan dalam kuesioner dapat menjadi indikator bagi variabel yang diukur. Pada Tabel 1 ditampilkan hasil nilai perhitungan convergent validity work engagement. 
Jurnal Manajemen Maranatha — Vol. 19 Nomor 2, Mei (2020)

Tabel 1. Outer loading, AVE, cronbach's alpha dan composite realibility atas variabel work engagement, service climate, job satisfaction, affective commitment, adapatability, dan career commitment

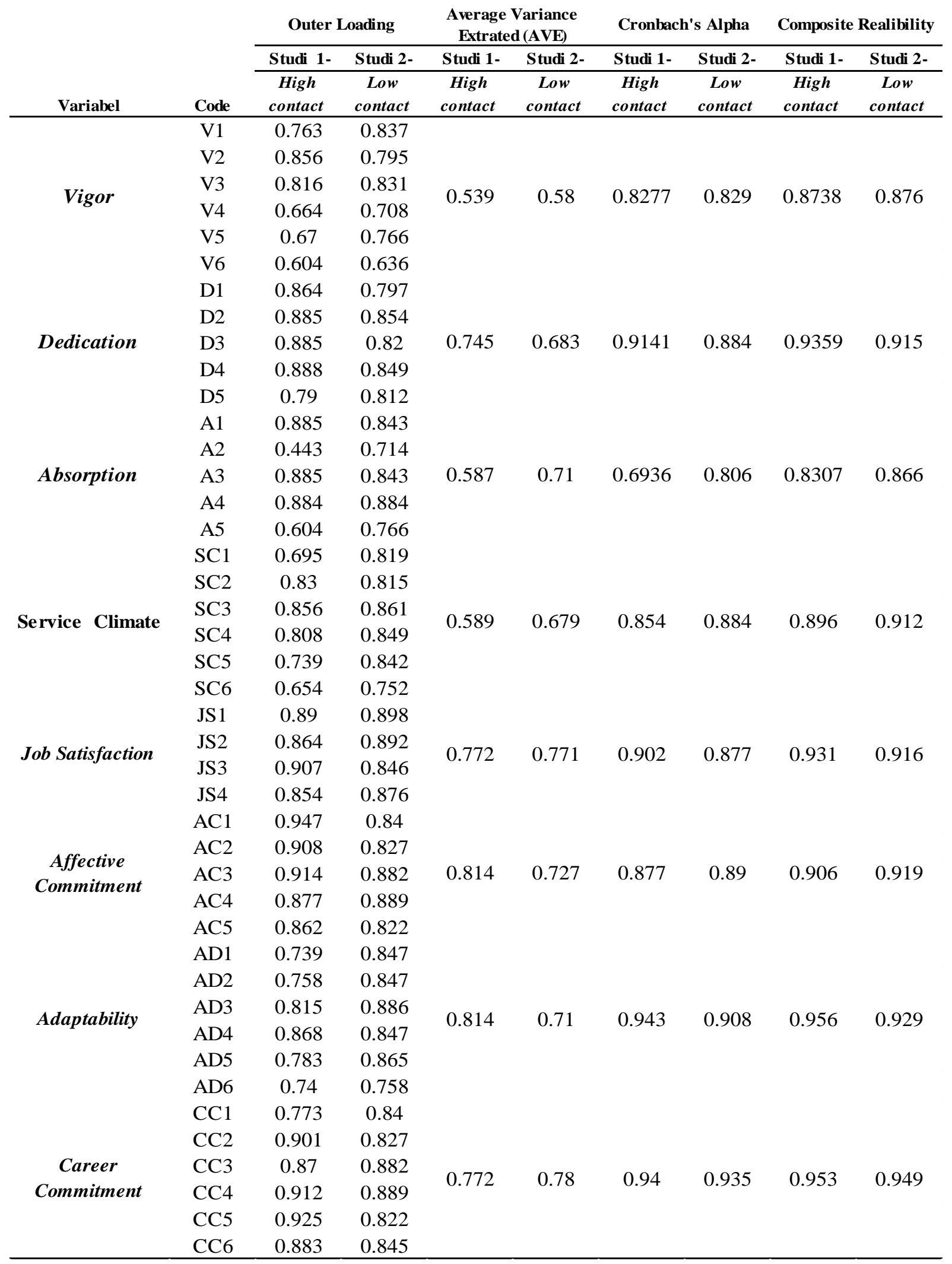

Sumber: Hasil pengolahan data smart PLS (2017) 
Hasil Tabel 1 memperlihatkan seluruh nilai outer loading dan dinyatakan layak untuk dilanjutkan ke tahap berikutnya, yakni di atas 0.50 . Nilai outer loading menunjukkan seberapa baik pernyataan atau indikator yang ada dalam kuesioner mampu mewakili variabel yang dimaksudkan.

Uji realibilitas dianalisa dengan melihat nilai composite realibility (CR) dan cronbach's alpha yang dapat dilihat dalam Tabel 1. Nilai CR dinyatakan reliable jika hasil perhitungannya menunjukkan hasil lebih besar dari 0.7 dan cronbach's alpha lebih besar dari 0.6 (Ghozali \& Latan 2015). Hasil pengolahan data menunjukkan semua variabel berada di atas nilai yang disyaratkan.

\section{Analisis Outer Model-Discriminant Validity}

Discriminant validity menilai seberapa jauh perbedaan dan korelasi antar variabel dengan menghitung $\sqrt{ }$ (akar) AVE melalui korelasi di antara variabel yang ada. Uji discriminant validity dinyatakan lulus apabila nilai korelasi antara variabelnya sendiri lebih tinggi dari korelasinya dengan variabel yang lain. Hasil uji disriminant validity dapat dilihat pada Tabel 2 dan Tabel 3 berikut ini.

Tabel 2. Uji discriminant validity studi 1 (high-contact)

\begin{tabular}{|c|c|c|c|c|c|c|c|c|}
\hline Studi 1 (High-Contact) & Absorption & Adaptability & $\begin{array}{c}\text { Affective } \\
\text { Commitment } \\
\end{array}$ & $\begin{array}{c}\text { Career } \\
\text { Commitment }\end{array}$ & Dedication & $\begin{array}{c}\text { Job } \\
\text { Satisfaction }\end{array}$ & $\begin{array}{l}\text { Service } \\
\text { Climate }\end{array}$ & Vigor \\
\hline Absorption & 0.904 & & & & & & & \\
\hline Adaptability & 0.495 & 0.785 & & & & & & \\
\hline Affective Commitment & 0.596 & 0.5 & 0.902 & & & & & \\
\hline Career Commitment & 0.615 & 0.444 & 0.689 & 0.879 & & & & \\
\hline Dedication & 0.811 & 0.452 & 0.722 & 0.774 & 0.863 & & & \\
\hline Job Satisfaction & 0.699 & 0.482 & 0.701 & 0.805 & 0.839 & 0.879 & & \\
\hline Service Climate & 0.71 & 0.519 & 0.588 & 0.612 & 0.783 & 0.703 & 0.767 & \\
\hline Vigor & 0.659 & 0.425 & 0.528 & 0.505 & 0.654 & 0.616 & 0.567 & 0.734 \\
\hline
\end{tabular}

Sumber: Hasil pengolahan data smart PLS (2017)

Tabel 3. Uji discriminant validity studi 2 (low-contact)

\begin{tabular}{|c|c|c|c|c|c|c|c|c|}
\hline Studi 2 (Low-Contact) & Absorption & Adaptability & $\begin{array}{c}\text { Affective } \\
\text { Commitment } \\
\end{array}$ & $\begin{array}{c}\text { Career } \\
\text { Commitment } \\
\end{array}$ & Dedication & $\begin{array}{c}\text { Job } \\
\text { Satisfaction }\end{array}$ & $\begin{array}{l}\text { Service } \\
\text { Climate } \\
\end{array}$ & Vigor \\
\hline Absorption & 0.864 & & & & & & & \\
\hline Adaptability & 0.539 & 0.842 & & & & & & \\
\hline Affective Commitment & 0.607 & 0.679 & 0.853 & & & & & \\
\hline Career Commitment & 0.49 & 0.71 & 0.665 & 0.883 & & & & \\
\hline Dedication & 0.646 & 0.542 & 0.644 & 0.612 & 0.827 & & & \\
\hline Job Satisfaction & 0.587 & 0.696 & 0.738 & 0.772 & 0.637 & 0.878 & & \\
\hline Service Climate & 0.555 & 0.63 & 0.673 & 0.671 & 0.772 & 0.717 & 0.824 & \\
\hline Vigor & 0.651 & 0.624 & 0.674 & 0.54 & 0.683 & 0.517 & 0.596 & 0.761 \\
\hline
\end{tabular}

Sumber: Hasil pengolahan data smart PLS (2017)

Keseluruhan hasil pengolahan tersebut dinyatakan valid karena hasil perhitungan $\sqrt{ }$ AVE masingmasing variabel adalah lebih besar dari nilai korelasi antar variabel dalam model. Sehingga variabelvariabel dalam penelitian ini dinyatakan layak untuk mengukur masing-masing variabel dalam penelitian ini dan dapat dilanjutkan analisisnya.

\section{Pengujian Inner Model (Struktural)}

Uji inner model dilakukan untuk menguji hubungan antara konstruk eksogen dan endogen yang telah dihipotesiskan sebelumnya. Menurut Moore, Notz, \& Flinger (2013), nilai r-square sebuah model berada di atas 0.7 dapat disimpulkan sebagai model yang kuat, berada di sekitar 0.5 adalah nilai yang moderat, sedangkan berada di sekitar 0.3 dapat dianggap lemah dan berada di bawah 0.3 berarti sangat lemah. Berdasarkan Tabel 4 dapat disimpulkan bahwa model penelitian yang dirancang termasuk dalam kategori moderat ke kuat. 
Jurnal Manajemen Maranatha — Vol. 19 Nomor 2, Mei (2020)

Tabel 4. Analisa $r$ - square studi 1 dan studi 2

\begin{tabular}{lll} 
Variabel & Studi 1 & Studi 2 \\
& & R \\
& R Square & Square \\
\hline Work Engagement & 0.765 & 0.638 \\
Vigor & 0.733 & 0.787 \\
Dedication & 0.884 & 0.827 \\
Absorption & 0.782 & 0.695 \\
Adaptability & 0.251 & 0.417 \\
Career Commitment & 0.527 & 0.399 \\
\hline
\end{tabular}

Sumber: Hasil pengolahan data smart PLS (2017)

\section{HASIL DAN PEMBAHASAN}

Pengujian hipotesis dilakukan dengan melihat nilai $t$-values dan $p$-values. Parameter $t$-values memberikan gambaran ada tidaknya hubungan atau pengaruh yang diestimasikan. Pengujian dalam penelitian ini merupakan pengujian one-tailed yakni sebesar $>1.96$ dengan significance level sebesar $5 \%$. Dengan kata lain, hasil riset tersebut memiliki tingkat kepercayaan (confidence interval) sebesar 95\% (Hair, Sarstedt, \& Ringle, 2011).

Parameter signifikansi $p$-values memberikan gambaran probabilitas signifikasi, yang mana $p$ values dibandingkan dengan nilai $\alpha=5 \%(0.05)$. Apabila $p$-values lebih kecil atau sama dengan dari $\alpha$ $=0.05$ maka dapat dikatakan hubungan atau pengaruh antar variabel itu signifikan, sedangkan jika lebih besar dari $\alpha=0.05$ maka dapat dikatakan hubungan atau pengaruh antar variabel tidak signifikan. $\alpha$ adalah batas kesalahan maksimal yang dijadikan patokan oleh peneliti (Sekaran \& Bougie, 2013).

Tabel 5. Hasil uji hipotesis studi 1 dan studi 2

\begin{tabular}{|c|c|c|c|c|c|c|c|}
\hline \multirow[b]{2}{*}{ Hipotesis } & \multirow[b]{2}{*}{ Uraian Hipotesis } & \multicolumn{2}{|c|}{ Studi 1} & \multicolumn{2}{|c|}{ Studi 2} & \multirow{2}{*}{$\begin{array}{c}\text { Studi } 1 \\
\text { Kesimpulan }\end{array}$} & \multirow{2}{*}{$\begin{array}{c}\text { Studi } 2 \\
\text { Kesimpulan }\end{array}$} \\
\hline & & $\begin{array}{c}\mathrm{T} \\
\text { Stat }\end{array}$ & $\begin{array}{c}\mathrm{P} \\
\text { Val }\end{array}$ & $\begin{array}{l}\mathrm{T} \\
\text { Stat }\end{array}$ & $\begin{array}{c}\mathrm{P} \\
\text { Val }\end{array}$ & & \\
\hline H1 & $\begin{array}{l}\text { Service } \\
\text { Climate } \rightarrow \text { Work } \\
\text { Engagement }\end{array}$ & 4.92 & 0.00 & 3.74 & 0.00 & Diterima & Diterima \\
\hline $\mathrm{H} 2$ & $\begin{array}{l}\text { Job Satisfaction } \rightarrow \\
\text { Work Engagement }\end{array}$ & 5.07 & 0.00 & 1.15 & 0.121 & Diterima & $\begin{array}{l}\text { Tidak } \\
\text { Dapat } \\
\text { Diterima }\end{array}$ \\
\hline H3 & $\begin{array}{l}\text { Affective } \\
\text { Commitment } \rightarrow \\
\text { Work Engagement }\end{array}$ & 2.22 & 0.01 & 3.74 & 0.00 & Diterima & Diterima \\
\hline $\mathrm{H} 4$ & $\begin{array}{l}\text { Work Engagement } \\
\rightarrow \text { Adaptability }\end{array}$ & 5.64 & 0.00 & 7.85 & 0.00 & Diterima & Diterima \\
\hline H5 & $\begin{array}{l}\text { Work Engagement } \\
\rightarrow \text { Carrer } \\
\text { Commitment }\end{array}$ & 12.85 & 0.00 & 9.30 & 0.00 & Diterima & Diterima \\
\hline
\end{tabular}

Sumber: Hasil pengolahan data smart PLS (2017) 
Berdasarkan hasil uji hipotesis pada hasil di atas, diperoleh hasil yakni lima hipotesis di kalangan karyawan FL high-contact dinyatakan signifikan dan dapat diterima. Sementara di kalangan karyawan FL low-contact, dari lima hipotesis yang diuji hanya empat hipotesis yang diterima dan ada satu hipotesis yang ditolak dan dinilai tidak signifikan.

Hasil uji keempat hipotesis (H1, H3, H4, dan H5) memiliki nilai $t$-value signifikan lebih besar dari 1.95 baik dalam studi di kalangan FL high-contact maupun low-contact. Dari nilai tersebut dapat simpulkan bahwa persepsi karyawan baik FL high-contact maupun low-contact terhadap service climate $(\mathrm{H} 1)$ dan affective commitment $(\mathrm{H} 2)$ diikuti oleh munculnya kondisi pikiran positif yang dikenal dengan nama work engagement. Pikiran positif yang dikenal dengan work engagement tersebut baik di kalangan karyawan baik FL high-contact maupun low-contact diikuti pula oleh munculnya perilaku adaptability (H4) dan career commitment (H5).

Sedikit berbeda dengan hipotesis 2 (H2), job satisfaction memiliki hubungan positif terhadap work engagement yang mana pada studi di kalangan FL high-contact, $t$-value signifikan sebesar 5.07, lebih besar dari 1.95. Namun pada studi di kalangan FL low-contact ditemukan berbeda di mana $t$-value tidak signifikan yakni sebesar 1.15, lebih kecil dari 1.95. Dari nilai tersebut dapat simpulkan bahwa job satisfaction (kepuasan kerja) di karyawan FL high-contact diikuti oleh munculnya kondisi pikiran positif yang dikenal dengan nama work engagement. Namun berbeda di kalangan karyawan $F L$ lowcontact yang mana job satisfaction tidak diikuti dengan kondisi pikiran positif work engagement. Hipotesis $\mathrm{H} 2$ tidak diterima, artinya job satisfaction (kepuasan kerja) karyawan FL low-contact tidak berpengaruh positif terhadap work engagement di kalangan karyawan FL low-contact.

Hasil uji hipotesis dalam penelitian ini tidak semuanya memperlihatkan hasil yang sama jika dibandingkan dengan penelitian sebelumnya yang dilakukan oleh Barnes \& Collier (2013). Perbedaan tersebut dapat disebabkan karena adanya perbedaan sampel penelitian dan demografis.

Hipotesis 1: persepsi atas service climate memiliki pengaruh positif terhadap work engagement. Industri perbankan, pendidikan, restoran, TV Kabel, internet provider, dan toko retail memiliki kompleksitas rantai nilai layanan dalam menciptakan pengalaman positif bagi pelanggannya. Ketidakakuratan dalam salah satu rantai nilai tersebut dapat mendatangkan tekanan keluhan dari pelanggan yang pada gilirannya dapat menciptakan rasa frustrasi dan rasa tidak berdaya di kalangan karyawan FL. Dalam hal ini maka dukungan rekan sekerja, standar kinerja yang mengutamakan kualitas layanan, serta penghargaan pimpinan dan perusahaan terkait peningkatan kualitas layanan terhadap karyawan FL menjadi sangat penting (Schneider \& Bowen, 1993). Dukungan, standar kinerja, dan penghargaan tersebut dapat memberikan emotional resources seperti rasa aman dan percaya diri. Rasa aman dan percaya diri yang kuat, sesuai teori JD-R dan Conservatory of Resources akan menjadi suatu dorongan yang dapat menghadirkan emosi positif karyawan terhadap suatu pekerjaan (work engagement).

Hipotesis 2: job satisfaction memiliki pengaruh positif terhadap work engagement di kalangan karyawan FL high-contact, namun tidak signifikan di karyawan FL low-contact. Berikut dua argumen untuk menjelaskan fenomena ini.

Pertama, tuntutan pekerjaan karyawan FL high-contact tentu berbeda dengan yang low-contact. Industri high-contact seperti perbankan, pendidikan, dan restoran tradisional misalnya mengharuskan sang karyawan untuk berinteraksi dengan pelanggan dalam waktu yang relatif lama, sementara yang low-contact relatif singkat. Dengan demikian maka kebutuhan emotional resources dari para karyawan FL high-contact diduga lebih tinggi dari yang low-contact. Oleh sebab itu kemungkinan besar emotional resources yang terkuras akibat tuntutan pekerjaan di kalangan low-contact sudah dapat tercukupi melalui kehadiran service climate (dukungan kolega, standar layanan, penghargaan, dan lainnya) dan komimen afektif (rasa keterhubungan personal) terhadap perusahaan. Temuan ini sejalan dengan teori COR (Conservatory of Resources) (Hobfoll, 1989; Hobfloll, 1990; Wright \& Cropanzano, 2000) yang menjelaskan bahwa setiap karyawan termotivasi untuk mencari dan menemukan sumber daya guna mengkompensasikan penurunan sumber daya (depletion of resources) akibat tuntutan pekerjaan.

Kedua, kemungkinan keterhubungan antara job satisfaction dengan work engagement di kalangan FL low-contact, bukanlah sebagai anteseden melainkan sebaliknya yakni luaran atau outcome dari work engagement. Pendapat ini didukung oleh beberapa pakar seperti Harter et al. (2002), Richman (2006), Lu, Lu, Gursoy, \& Neale (2015), dan Karatepe (2012). Hal ini seiring dengan analisis beberapa pakar yang juga telah menggarisbawahi bawah kepuasan kerja bukanlah prediktor terbaik 
untuk semangat kerja atau work engagement (Staw, 1986). Penelitian Wright \& Cropanzano (2000) menemukan bahwa semangat kerja yang muncul dalam bentuk kinerja (job performance) tidaklah memiliki korelasi dengan ukuran-ukuran terkait job satisfaction.

Hipotesis 3: affective commitment memiliki pengaruh positif terhadap work engagement. Rasa peduli, loyalitas, dan keterhubungan pribadi dengan perusahaan merupakan salah satu unsur pembentuk dari work engagement, baik bagi karyawan FL baik high-contact dan low-contact. Komitmen afektif terhadap perusahan tersebut merupakan bentuk job resource yang sangat penting. Selain dapat menjadi penyeimbang dari tuntutan pekerjaan yang mendatangkan stres, komitmen afektif rupanya dapat melahirkan emosi positif dan antusiasme bekerja.

Hipotesis 4: work engagement memiliki pengaruh positif terhadap adaptability. Kondisi pikiran positif dan antusiasme bekerja yang kuat dalam teori broaden and build (Fredrikson, 2004) dapat memperluas (broadening) area kesadaran dan keterampilan seseorang. Dalam konteks pekerjaan, karyawan $F L$ saat bertemu dengan pelanggan yang menjelaskan kebutuhannya, karyawan yang memiliki work engagement yang tinggi akan secara otomatis memiliki perasaan empati. Perasaan empati tersebut akan diikuti perilaku inisiatif dan adaptatif untuk mencari cara penyelesaian terbaik.

Hipotesis 5: work engagement memiliki pengaruh positif terhadap career commitment. Kondisi pikiran positif yang kuat dalam teori broaden and build (Fredrikson, 2004) dapat membangun (building) ketertarikan seseorang untuk memperkaya dirinya dengan melakukan eksplorasi bidang tertentu secara lebih mendalam. Dalam konteks karyawan $F L$, hal itu berwujud dalam bentuk lahirnya kebanggaan terhadap posisi karir karyawan $F L$. Kebanggaan tersebut berimplikasi misalnya ke mana pun karyawan $F L$ ini pindah bekerja, karir sebagai $F L$ akan senantiasa menjadi pilihan utama dibanding dengan back office.

\section{SIMPULAN DAN SARAN}

Semua karyawan $F L$ membutuhkan sumber daya (sumber emosi positif) guna mengkompensasikan penurunan sumber daya (depletion of resources) akibat tuntutan pekerjaan (job demand). Sumber daya yang dapat diandalkan oleh karyawan $F L$ untuk memelihara emosi positif dan semangat kerja (work engagement) adalah service climate (berbentuk dukungan rekan sekerja, standar layanan, penghargaan dari perusahaan, dan lainnya), job statisfaction (berupa kepuasan dan kebermaknaan personal atas pekerjaan tersebut), serta commitment affective (berupa kebanggaan dan keterhubungan personal dengan sejarah perusahaan yang menaunginya).

Khusus bagi para karyawan low-contact, faktor service climate (berbentuk dukungan rekan sekerja, standar layanan, penghargaan dari perusahaan, dan lainnya) serta commitment affective (berupa kebanggaan dan keterhubungan personal dengan sejarah perusahaan yang menaunginya) dapat menjadi penentu kualitas work engagement mereka.

Sedikit berbeda bagi kelompok karyawan high-contact, selain service climate (berbentuk dukungan rekan sekerja, standar layanan, penghargaan dari perusahaan, dan lainnya) serta commitment affective (berupa kebanggaan dan keterhubungan personal dengan sejarah perusahaan yang menaunginya), juga ada faktor job satisfaction (berupa kebermakaan kerja) yang menentukan kualitas dan semangat kerja mereka. Karyawan $F L$ yang memiliki work engagement akan mengalami perluasan kesadaran dan keterampilan yang berwujud dalam perilaku yang fleksibel, kreatif, dan terbuka dalam hal melayani pelanggan (perilaku adaptative) dan juga perilaku career commitment, seperti keinginan untuk mempertahankan dan memperdalam karir $F L$ dibandingkan karir di back office.

Perusahaan dan para praktisi SDM yang ingin mendorong karyawan $F L$ untuk lebih berinisiatif, produktif, dan berkomitmen, harus memperhatikan sisi kondisi pikiran positif mereka dalam bekerja (work engagement). Kondisi pikiran positif dalam bekerja (work engagement) dapat diperoleh dari emotional resources (sumber daya pendukung semangat kerja). Untuk karyawan FL high-contact sumber daya tersebut dapat dikembangkan oleh para lini manajer dan praktisi SDM dengan menyiapkan tiga kondisi ini, yakni (a) membangun service climate yang baik, seperti terciptanya dukungan rekan sekerja, standar layanan yang dapat dipahami, serta penghargaan dari atasan dan perusahaan; (b) memperkuat komunikasi mengenai employer brand image di mata karyawan dan membangun relasi personal dengan mereka (commitment affective); serta (c) mengkomunikasikan dampak positif dari pekerjaannya bagi banyak orang (job satisfaction). Untuk karyawan low-contact, 136 
perusahaan dan praktisi SDM hanya perlu memperhatikan dua kondisi ini saja, yakni (a) service climate dan (b) commitment affective mereka.

\section{REFERENSI}

Allen, N. J., \& Meyer, J. P. (1990). The measurement and antecedents of affective, continuance and normative commitment to the organization. Journal of Occupational Psychology, Vol. 63, 1-18

Amabile, T., \& Kramer, S. (2011). The progress principle: using small wins to ignite joy, engagement, and creativity at work. Boston, MA: Harvard Business Review Press

Bakker, A. B. \& Demerouti, E. (2007). The job demands-resources model: state of the art. Journal of Managerial Psychology, Vol. 22 (3), 309-328. DOI: 10.1108/02683940710733115

Barnes, D. C., \& Collier, J. E. (2013). Investigating work engagement in the service environment. Journal of Services Marketing, Vol. 27 (6), 485- 499

Benson-Armer, R. (2015). Building capabilities for performance, Mckinsey \& company-organization: our insight. Diperoleh dari: https://www.mckinsey.com/business-functions/organization/ourinsights/building-capabilities-for-performance

Coelho, F., Augusto, M., \& Lages, L.F. (2011). Contextual factors and the creativity of FL employees: the mediating effects of role stress and intrinsic motivation. Journal of Retailing. Vol. 87 (1), 3145

De Lange, A.H., de Witte, H., \& Notelaers, G. (2008). Should I stay or should I go? examining longitudinal relations among job resources and work engagement for stayers versus movers. Work and Stress, Vol. 22 (3), 201-223

Demerouti, E., \& Cropanzano, R. (2010). From thought to action: employee work engagement and job performance, in Bakker, A.B. \& Leiter, M.P. (Eds). Work Engagement: A Handbook of Essential Theory and Research, New York, NY: Psychology Press, 147-163

Fredrickson, B.L. (1998). What good are positive emotions?. Review of General Psychology, Vol. 2 (3), 300-319

Fredrickson, B.L. (2001). The role of positive emotions in positive psychology. American Psychologist, Vol. 56 (3), 218-226

Fredrickson, B.L. (2004). Gratitude, like other positive emotions, broadens and builds, in Emmons, R.A. \& McCullough, M.E. (Eds). The psychology of gratitude. New York: University Press, 145166

George, J.M. (1989). Mood and absence. Journal of Applied Psychology, Vol. 74, 317-324

Ghozali, I., \& Latan, H. (2015). Partial least squares: konsep, teknik dan aplikasi menggunakan program smart PLS 3.0 untuk penelitian empiris. Semarang: Badan Penerbit Universitas Diponegoro

Gorgievski, M., Bakker, A.B. \& Schaufeli, W.B. (2010). Work engagement and workaholism: comparing the self-employed and employees on payroll. Journal of Positive Psychology, Vol. 5, 83-86

Gwinner, K.P., Bitner, M.J., Brown, S.W., \& Kumar, A. (2005). Service customization through employee adaptiveness. Journal of Service Research, Vol. 8 (2), 131-148. Diperoleh dari https://doi.org/10.1177/1094670505279699

Hair, J.F., Sarstedt, M., \& Ringle, C.M. (2011). An assessment of the use of partial least squares structural equation modeling in marketing research. Journal of the Academy of Marketing Science. Vol. 40, 414-433. https://doi.org/10.1007/s11747-011-0261-6

Hakanen, J.J., Perhomeini, R., \& Toppinen-Tanner, S. (2008). Positive gain spirals at work: from job resources to work engagement, personal initiative, and work-unit innovativeness. Journal of Vocational Behavior, Vol. 73, 78-91

Harter, J.K., Schmidt, F.L., \& Hayes, T.L. (2002). Business-unit-level relationship between employee satisfaction, employee engagement, and business outcomes: a meta-analysis. Journal of Applied Psychology, Vol. 87 (2), 268-279

Hobfoll, S.E. (1989). Conservation of resources: a new attempt at conceptualizing stress. American Psychologist, Vol.44, 513-524 
Hobfoll, S.E. (1990). The importance of predicting, activating, and facilitating social support. Journal of Social and Personal Relationships, Vol. 7, 435-436

Homburg, C., \& Stock, R.M. (2004). The link between salespeople's job satisfaction and customer satisfaction in a business-to-business context: a dyadic analysis. Journal of the Academy of Marketing Science, Vol. 32, 144-158

Isen, A.M. (1984). The influence of positive affect on decision making and cognitive organization. Advances in Consumer Research, Vol. 11 (1), 534-537

Johlke, M., \& Duhan, D. (2000). Supervisor communication practices and service employee job outcomes. Journal of Service Research, Vol. 3, 154-165. DOI: 10.1177/109467050032004.

Johnson, J. (1996). Linking employee perceptions of service climate to customer satisfaction. Personnel Psychology, Vol. 49, 831-851. DOI: 10.1111/j.1744-6570.1996.tb02451.x

Karatepe, O.M. (2012). Job resources, work engagement, and hotel employee outcomes: a time-lagged analysis. Economic Research, Vol. 25, 644-665

Karlsson, J., \& Skålén, P. (2015). Exploring front-line employee contributions to service innovation. European Journal of Marketing, Vol. 49 (9/10), 1346-1365. Diperoleh dari https://doi.org/10.1108/EJM-10-2012-0568

Kaufman, J., Markey, R., Burton, S.D., \& Azzarello, D. (2013). Who's responsible for employee engagement. Diperoleh dari: http://www.bain.com/publications/articles/whos-responsible-foremployee-engagement.aspx

Kim, P.B., Lee, G., \& Murrmann, S.K. (2009). Moderating effects of gender and organizational level between role stress and job satisfaction among hotel employees. International Journal of Hospitality Management, Vol. 28 (4), 612-619

Kular, S., Gatenby, M., Rees, C., Soane, E., \& Truss, K. (2008). Employee engagement: a literature review. Kingston Business School Working Paper, Series No. 19

Locke, A.E. (1976). The nature and causes of job satisfaction, in Dunnette, M.D. (Ed.), Handbook of Industrial and Organizational Psychology, Rand McNally, Chicago, IL, 1297-1349

Lu, L., Lu, A.C.C., Gursoy, L.D., \& Neale, N.R. (2016). Work engagement, job satisfaction, and turnover intentions: a comparison between supervisors and line-level employees. International Journal of Contemporary Hospitality Management Vol. 28 (5)

Lybomirsky, S., King, L., \& Diener, E. (2005). The benefits of frequent positive affect: does happiness lead to success?. Psychological Bulletin, Vol. 131, 803-855

Macey, W.H., \& Schneider, B. (2008). The meaning of employee engagement. Industrial and Organizational Psychology, Vol. 1 (1), 3-30

Macey, W.H., Schneider, B., Barbara, K.M., \& Young, S.A. (2009). Employee engagement: tools for analysis, practice, and competitive advantange. Malden, MA: Wiley-Blackwell

Maslach, C., Schaufeli, W.B., \& Leiter, M.P. (2001). Job burnout. Annual Review of Psychology, Vol. 52, 397-422

Mechinda, P., \& Patterson, P.G. (2011). The impact of service climate and service provider personality on employees' customer-oriented behavior in a high-contact setting. Journal of Services Marketing, Vol. 25 (2), 101-113

Moore, D.S., Notz, W.I, \& Flinger, M.A. (2013). The basic practice of statistics (6th ed.). New York, NY: W.H. Freeman and Company.

Mowday, R.T., Steers, R.M., \& Porter, L.W. (1979). The measurement of organizational commitment. Journal of Vocational Behavior, Vol. 14, 224-247

Parish, J.T., Berry, L.L., \& Lam, S.Y. (2008). The effect of the servicescape on service workers. Journal of Service Research, Vol. 10, 220-238

Pelled, L.H., \& Xin, K.R. (1999). Down and out: an investigation of the relationship between mood and employee withdrawal behavior. Journal of Management, Vol. 25 (6), 875-895

Plouffe, C., Bolander, W., Cote, J.A., \& Hochstein, B. (2015). Does the customer matter most? exploring strategic FL employees' influence of customers, the internal business team, and external business partners. Journal of Marketing, American Marketing Assciation

Richman, A. (2006). Everyone wants, an engaged workforce; how can you create it? Workspan, Vol. 49, 36-39 
Salanova, M., \& Schaufeli, W.B. (2008). A cross-national study of work engagement as a mediator between job resources and proactive behavior. International Journal of Human Resource Management, Vol. 19 (1), 116-131

Schaufeli, W.B., \& Bakker, A.B. (2004). Job demands, job resources, and their relationship with burnout and engagement: a multi-sample study. Journal of Organizational Behavior, Vol. 25 (3), 293-315

Schaufeli, W.B., \& Bakker, A.B. (2010). Defining and measuring work engagement: bringing clarity to the concept", in Bakker, A.B. \& Leiter, M.P. (Eds). Work Engagement: A Handbook of Essential Theory and Research, New York: Psychology Press, 25-38

Schneider, B., \& Bowen, D.E. (1993). The service organization: human resources management is crucial. Organizational Dynamics, Vol. 21 (4), 39-52

Sekaran, U., \& Bougie, R. (2013). Research methods for business. $5^{\text {th }}$ Ed. West Sussex: John Wiley and Sons

Staw, B.M. (1986). Organizational psychology and the pursuit of the happy/productive worker. California Management Review, Vol. 28 (4), 40-53

Spector, R., \& McCarthy, P. (2005). The nordstrom way to customer service excellence. Hoboken, NJ: Wiley

Tajfel, H., \& Turner, J. (1985). The social identity theory of intergroup behavior, in Worchel, S. \& Austin, W.G. (Eds). Psychology of Intergroup Behavior, 2nd ed. Chicago, IL: Nelson-Hall, 7-24

Wang, G., \& Netemeyer, R.G. (2004). Salesperson creative performance: conceptualization, measurement, and nomological validity. Journal of Business Research, Vol. 57 (8), 805-12

Wellins, R. \& Concelman, J. (2005). Creating a culture for engagement. Diperoleh dari http://www.tomorrowtodayglobal.com/2006/09/26/creating-a-culture-foer-engagement/

Wright, T.A., \& Cropanzano, R. (2000). Psychological well-being and job satisfaction as predictors of job performance. Journal of Occupational Health Psychology, Vol. 5 (1), 84-94 
Jurnal Manajemen Maranatha ש Vol. 19 Nomor 2, Mei (2020) 